\title{
POLA INTERAKSI BAKTERI ENDOFITIK +GFP (GREEN FLUORESCENT PROTEIN) DALAM JARINGAN TANAMAN PADI (Oryza sativa L.)
}

\author{
Sufianto $^{1}$, Ali Ikhwan ${ }^{2}$, M. Sahrul ${ }^{3}$ \\ ${ }^{1,2}$ Departemen Agroteknologi, Fakultas Pertanian dan Peternakan \\ ${ }^{3}$ Mahasiswa Agroteknologi, Fakultas Pertanian dan Peternakan \\ Universitas Muhammadiyah Malang, Malang, Indonesia \\ Email: aliikhwan64@gmail.com
}

\begin{abstract}
This study was intended to examine the pattern of interaction and mutant distribution of endophytic bacteria as a result of the transformation of the gfp gene in rice plant tissue in vitro. This study used 5 isolates of rice endophytic gfp mutants namely IM-1, IM-3, IM-8, IM-24, IM-25. The study was conducted in two stages, stage I using a simple Complete Complete Design (RAL) and stage II using factorial Complete Randomized Design (RAL) with a factor of 1: the type of plant tissue and factor 2: the type of mutant isolates.The results of the study of patterns of bacterial interactions in rice tissue culture showed that the percentage of infections of $5 \mathrm{gfp}$ mutant endophytic bacteria isolates ranged from $4 \%-17 \%$. The highest percentage was in mutant isolates IM-3 + gfp $(17 \%)$ and the lowest was in mutants IM-8 + gfp (4\%). The interaction pattern was not significantly different from the parameters of seed germination time. On the other hand, in observing the distribution of bacteria that infect rice tissue, they showed different pattern. Mutant IM-1 + gfp infection is higher in stem tissue, whereas $I M-24+$ gfp mutant infection is higher in root tissue and IM-25 + gfp mutant infection is higher in leaf tissue. Mutant infection of IM-25 + gfp in leaves had the highest number of colonies reaching $1.64 \times 109 \mathrm{cfu} / \mathrm{ml}$.
\end{abstract}

Keywords: Mutants, endophytic bacteria, rice, interactions

\section{PENDAHULUAN}

Padi (Oryza sativa L.) merupakan salah satu tanaman budidaya terpenting dalam peradaban manusia. Pada saat ini produksi padi dunia menempati urutan ketiga dari semua serealia setelah jagung dan gandum (Purnamaningsih, 2006). Produktivitas padi nasional pada tahun 2015 mengalami peningkatan 4.514 .783 ton/ha atau 6,37\% dari tahun 2014 (BPS, 2016). Apabila produktivitas ini tidak di pertahankan atau malah mengelami pennurunan, Indonesia akan mengalami defisit beras pada tahun 2020 hingga mencapai 9,7 juta ton apabila tidak dilakukan peningkatan produksi secara nyata. (JICA, 1997 dalam Maftuchah : 2012).

Upaya peningkatan produksi dapat dilakukan dengan menggunakan varietas unggul, perbaikan teknis budidaya, lingkungan, serta pemanfaatan mikroorganisme yang mampu bersimbiosis mutualisme dengan tanaman padi dalam peningkatan produksi, baik dalam penyediaan unsur hara (UH), sinstesis Growth Hormone $(\mathrm{GH})$, dan lain sebagainya. 
Sebaran dan distribusi PGPB tentunya akan mempengaruhi produksi tanaman yang akan berhubungan dengan bahan yang disintesis oleh bakteri tersebut. Beberapa tanaman memiliki pola unik yang berhubungan dengan distribusi dan sintesis hormon. Oleh karena itu, belum diketahui pola interaksi dan distribusi dalam jaringan tanaman padi.

Penelitian ini dimaksudkan untuk mengetahui lebih lanjut mengenai pola interaksi dan distribusi bakteri menggunakan bakteri mutan endofitik yang telah di transformasi dengan menyisipkan gen $g f p$ pada masing-masing isolat bakteri tersebut.

\section{BAHAN DAN METODE PENELITIAN}

Penelitian ini dilaksanakan di Laboratorium Kultur Jaringan, Kebun Benih Hortikultura Sidomulyo, Laboratorium Agronomi, dan Laboratorium Bioteknologi Universitas Muhammadiyah Malang selama 5 bulan mulai bulan Juli sampai Desember 2016.

Alat yang digunakan adalah Laminar Air Flow Cabinet (LAFC), Autoclaf, pinset, gelas ukur, botol kultur, cawan petri, erlenmayer 500ml, timbangan analitik, sprayer, coloni counter, sentrifuge, microwave, UV Iluminator, mortal martil steril.

Bahan yang digunakan adalah alkohol 70\%, Clorox $10 \%$ dalam Bayclin $2.52 \% \mathrm{CaCl}_{2}$, media Murashige and Skoog (MS), media padat Luria Bertani (LB)+arabinose L, aquades steril, benih padi (Oriza sativa L.), isolat mutan bakteri endofitik +gfp (IM-1, IM-3, IM-8, IM24, IM-25).

Penelitian ini dilakukan dengan tahapan sterilisasi alat dan bahan yang dilakukan dengan menggunakan autoklaf pada suhu $121{ }^{\circ} \mathrm{C}$ dengan tekanan 1 atm. Media yang digunakan adalah media Murashige and Skoog (MS) sebagai media tanam, dan media Luria Bertani (LB) sebagai media pengamatan distribusi bakteri. Bahan tanam berupa benih di steril dengan alkohol $70 \%$ selama 5 menit kemudian dibilas dengan akuades steril. Setelah itu di steril dengan klorox $10 \%$ selama 3 menit dan dibilas dengan akuades steril. Setelah steril benih di rendam dalam inoculum isolate mutan bakteri endofitik + $g f p$ selama 2 jam setelah itu di tanam dalam media tumbuh (MS).

Planlet yang berumur 1 bulan di ektraksi dengan metode Ikhwan (2008) dalam Dyah (2009) dengan memisahkan antara organ akar, batang, dan daun dan di gores dalam media Luria Bertani (LB)

Penelitian ini dilakukan 2 tahap, tahap I menggunakan Rancangan Acak Lengkap (RAL) sederhana dengan Perlakuan Kontrol, Mutan Bakteri endofitik + gfp (IM-1, IM-3, IM8, IM-24, IM-25) dan Tahap II menggunakan Rancangan Acak Lengkap (RAL) faktorial 
dengan faktor 1 yakni Organ $(\mathrm{O})$; $\mathrm{O} 1$ = Organ Daun, $\mathrm{O} 2$ = Organ Batang, $\mathrm{O} 3$ = Organ Akar; dan factor 2 jenis isolat mutan; Kontrol, Mutan Bakteri endofitik +gfp (IM-1, IM-3, IM-8, IM-24, IM-25). Masing masing kombinasi perlakuan di ulang sebanyak 3 kali dengan pengenceran $10^{1}, 10^{2}, 10^{3}, 10^{4}, 10^{5}, 10^{6}$, dan $10^{7}$. Parameter yang diamati adalah Persentase imbibisi benih (\%), Waktu perkecambahan benih (hst), jumlah koloni pada masing masing organ (Log $c f u / \mathrm{ml})$ dan jumlah koloni masing masing isolate $(c f u / \mathrm{ml})$

Parameter yang diamati adalah 1) Persentase imbibisi benih padi (\%) yang diamati dengan cara menimbang berat benih sebelum (a) dan sesudah (b) perendaman benih dan dihitung dengan rumus:

$\%$ imbibisi $=\frac{\mathrm{a}}{\mathrm{b}} \times 100 \%$

2) Waktu berkecambah (hsi). diamati dengan cara mengamati hari pertama benih berkecambah yang ditandai dengan munculnya radikula dan plumula sejak penanaman. 3) Jumlah koloni bakteri $(\log c f u / m l)$ Jumlah koloni bakteri menunjukkan distribusi bakteri dalam jaringan tanaman yang diamati dengan menghitung jumlah koloni yang terbentuk pada masing masing organ.

\section{HASIL DAN PEMBAHASAN}

\section{Uji Persentase Imbibisi Benih dalam Isolat Bakteri}

Imbibisi merupakan suatu proses awal dalam perkecambahan benih. Imbibisi sangat dipengaruhi oleh adanya faktor yang mempercepat imbibisi benih. Mengemukakan bahwa terdapat 3 faktor utama dalam imbibisi benih yakni permeabilitas kulit benih, komposisi kimia benih, jenis benih. Imbibisi merupakan proses masuknya air kedalam jaringan benih guna mengaktifkan menginaktifkan dormansi benih yang terjadi sebelumnya dengan adanya enzim amylase yang berperan sebagai pengurai amilum yang tersimpan dalam endosperm, setelah itu terjadi respirasi benih dan terjadi penguraian bahan bahan yang melarut dan ditranslokasikan ke titik-titik tumbuh tanaman padi.

Pada Tabel 1 Terlihat bahwa persentase imbibisi inoculum benih ke isolat mutan yang memiliki kepekatan yang relative sama cenderung berbeda antar isolat. Pada isolat mutan IM$3+g f p$ menunjukkan persentase imbibisi yang cenderung lebih tinggi (17\%) dari pada isolat mutan yang lain. Hal ini menunjukkan bahwa isolat mutan im-3 memiliki potensial osmotic yang lebih tinggi dari pada isolat yang lain. Potensial osmotic ini akan menyebabkan terjadinya proses difusi osmosis yang berhubungan dengan teradinya imbibisi pada benih. 
Kamil (1979) Menyatakan bahwa difusi merupakan perpindahan senyawa dari konsentrasi tinggi ke konsentrasi rendah tanpa melalui membrane selektif permeable. sedangkan osmosis adalah perpindahan senyawa dari potensial air tinggi ke potensial air rendah melalui membrane selektif permeable.

Tabel 1. Persentase Imbibisi Benih

\begin{tabular}{lccc}
\hline \multirow{2}{*}{ Isolat/Larutan } & \multicolumn{2}{c}{ Berat benih $(\mathrm{g})$} & \multirow{2}{*}{ Persentase } \\
\cline { 2 - 3 } & Sebelum & Setelah & $10 \%$ \\
\hline $\mathrm{dH}_{2} \mathrm{O}$ & 0.45 & 0.50 & $12 \%$ \\
Media LB & 0.43 & 0.48 & $11 \%$ \\
Mutan IM-1+gfp & 0.45 & 0.50 & $17 \%$ \\
Mutan IM-3+gfp & 0.44 & 0.52 & $4 \%$ \\
Mutan IM-8+gfp & 0.45 & 0.47 & $11 \%$ \\
Mutan IM-24+gfp & 0.44 & 0.49 & $10 \%$ \\
Mutan IM-25+gfp & 0.43 & 0.47 & $\mathbf{1 1 \%}$ \\
\hline \multicolumn{1}{c}{ Rerata } & $\mathbf{0 . 4 4}$ & $\mathbf{0 . 4 9}$ & \\
\hline
\end{tabular}

Persentase imbibisi pada masing masing isolat memiliki persentase yang relative lebih tinggi daripada larutan $\mathrm{dH}_{2} \mathrm{O}$, tetapi memiliki persentase yang lebih rendah dari pada media LB. hal ini dikarenakan adanya pertumbuhan isolat bakteri yang menyebabkan konsentrasi isolat lebih tinggi dari pada $\mathrm{dH}_{2} \mathrm{O}$ dan lebih rendah dari pada media LB. akan tetapi media LB memiliki tekanan osmosis yang lebih tinggi daripada $\mathrm{dH}_{2} \mathrm{O}$ sehingga terlihat bahwa pada media LB benih memiliki persentase yang lebih tinggi (12\%). Dengan adanya perbedaan konsentrasi dan tekanan osmosis inilah yang menyebabkan larutan dan isolat bakteri mutan mampu masuk kedalam benih.

Menurut Salisbury dan Ross (1992), air merupakan syarat terjadinya perkecambahan biji karena air berperan dalam :

1. Melunakkan kulit biji embrio dan endosperm mengembang sehingga kulit biji robek.

2. Memfasilitasi masuknya $\mathrm{O}_{2}$ ke dalam biji, gas masuk secara difusi sehingga suplai $\mathrm{O}_{2}$ pada sel hidup meningkat dan pernafasan aktif.

3. Alat transport larutan makanan dari endosperm atau kotiledon.

Pada dasarnya proses imbibisi yang terjadi di dalam biji tumbuhan meliputi dua proses yang berjalan bersama-sama yaitu proses difusi dan osmosis. Dikatakan proses difusi karena air bergerak dari larutan yang lebih rendah konsentrasinya di luar biji, masuk ke dalam zat di dalam biji yang mempunyai konsentrasi lebih tinggi sedangkan proses osmosis tidak lain terjadi karena kulit biji bersifat permeabel terhadap molekul-molekul, sehingga air dapat masuk ke dalam biji melalui pori-pori yang ada di dalam kulit biji. Pada Imbibisi tidak ada 
keterlibatan membran, seperti pada osmosis. Imbibisi terjadi karena permukaan strukturstruktur mikroskopik dalam sel tumbuhan seperti selulosa, butir pati, protein dan bahan lainnya menarik dan memegang molekul-molekul air dengan gaya tarik antar molekul. Dengan kata lain imbibisi terjadi oleh potential matrik (Tjitrosomo, 1985)

Pada proses imbibisi juga dipengaruhi oleh kadar atau konsentrasi larutan sama seperti pada proses difusi dan osmosis. Beberapa faktor yang mempengaruhi kecepatan penyerapan air oleh biji diantaranya adalah (Kamil, 1979 ) Konsentrasi air, Tekanan hidrostatik, Daya intermolekular, Luas permukaan biji yang kontak dengan air, Suhu, Spesies dan varietas, Umur, Tingkat kemasakan, Komposisi kimia.

Pola interaksi bakteri dapat terlihat dari adanya persentase imbibisi pada masing masing perlakuan. Dengan adanya imbibisi benih menunjukkan tahapan invasi awal bakteri melalui imbibisi. Imbibisi akan memacu perkecambahan benih yang akan tumbuh dan berkembang menjadi tanaman lengkap. Ketika proses pertumbuhan tanaman, bakteri yang berada pada benih turut menyebar seiring tumbuh kembang tanaman. Pada saat tanaman memiliki organ yang lengkap, bakteri terlarut dalam kelarutan mineral yang diserap akar tanaman.

\section{Waktu Perkecambahan Benih Padi secara In Vitro}

Berdasarkan pada Tabel 2 terlihat bahwa perlakuan perendaman benih pada masing masing isolat bakteri menunjukkan berbeda tidak nyata pada uji BNJ 5\%. Rerata waktu perkecambahan menunjukkan bahwa perandaman inokulum yang dilakukan pada isolat bakteri mutan berbeda tidak nyata. Hal ini dikarenakan isolat yang masuk melaui proses imbibisi tidak memberikan pengaruh yang nyata dalam waktu berkecambah benih. Hal ini menunjukkan bahwa dalam waktu perkecambahan benih, faktor yang sangat mempengaruhi adalah kondisi endosperm dan viabilitas benih. Viabilitas merupakan kemampuan benih untuk berkecambah menjadi individu baru dan mengakhiri masa dormansi benih. Sutopo (2002) menyebutkan bahwa terdapat perbedaan penyerapan air oleh benih pada masing masing tahapan. Penyerapan air yang akan tetap berlangsung sampai benih memiliki kandungan air yang berkisar antara 40\%-60\% pada tahap pertama. Setelah itu, akan meningkat menjadi 70\%-90\% pada saat kecambah tumbuh karena telah muncul radikula dan jaringan penyimpanan. 
Tabel 2. Rerata Waktu Perkecambahan Benih Padi

\begin{tabular}{lc}
\hline \multicolumn{1}{c}{ Perlakuan } & Rerata (hari) \\
\hline Kontrol & $6.0 \mathrm{a}$ \\
Mutan IM-1+gfp & $6.8 \mathrm{a}$ \\
Mutan IM-3+gfp & $6.6 \mathrm{a}$ \\
Mutan IM-8+gfp & $7.1 \mathrm{a}$ \\
Mutan IM-24+gfp & $7.2 \mathrm{a}$ \\
Mutan IM-25+gfp & $6.6 \mathrm{a}$ \\
\hline BNJ 5\% & 2.297
\end{tabular}

Keterangan : angka-angka yang diikuti huruf yang sama pada kolom yang sama menunjukkan berbeda tidak nyata pada uji BNJ 5\%

Perkecambahan benih merupakan tahap awal pertumbuhan dan perkembangan tanaman. Tahapan ini merupakan berkembangnya struktur-struktur penting dari embrio benih yang menunjukan kemampuannya untuk menjadi kecambah dengan ditandai munculnya radikula yang menembus kulit biji. Terdapat beberapa faktor yang mempengaruhi perkecambahan benih yaitu factor eksternal dan faktor internal. Faktor eksternal benih yaitu suhu, air dan cahaya. Ketersediaan air merupakan salah satu faktor penting yang harus di penuhi agar benih dapat berkecambah. Faktor internal benih yaitu tingkat kemasakan benih, ukuran benih dan dormansi. Dormansi merupakan fenomena fisiologis benih yang menunjukan ketidakmampuan benih untuk berkecambah pada kondisi optimum. Pada umumnya dormansi pada benih memerlukan kondisi lingkungan tertentu seperti ketersediaan air dan adanya cahaya sehingga dormansi dapat berakhir. Lama waktu dormansi pada benih bervariasi bergantung pada species dan kondisi lingkungan (Campbell, 2003).

\section{Rerata Koloni Isolat Bakteri Mutan gfp pada Masing-Masing Organ Tanaman Padi Organ Akar}

Pada Gambar 4 terlihat bahwa isolat Mutan IM-24+gfp menunjukkan berbeda sangat nyata dengan isolat Mutan IM-3+gfp dalam jumlah koloni bakteri pada organ daun. Hal ini menunjukkan pula bahwa setiap isolat memiliki distribusi yang berbeda yang telihat pula pada tabel 3. Perbedaan distribusi bakteri inilah yang menjadikan setiap isolat bakteri memiliki karakteristik dan pola interaksi tersendiri yang sangat dipengaruhi oleh jenis inang dan pola interaksinya. Mattos, et. al., 2008 menemukan bahwa pada hasil isolasi bakteri endofitik yang dilakukan juga terdapat perbedaan jumlah koloni pada akar dan pucuk padi yakni $8.5 \times 10^{9}$ pada akar dan 2.95 x $10^{6} \mathrm{CFU/g}$ planlet. Mattos et. al. (2008) juga menerangkan bahwa jumlah koloni pada akar memiliki nilai rerata yang lebih tinggi dari pada batang dan daun. 


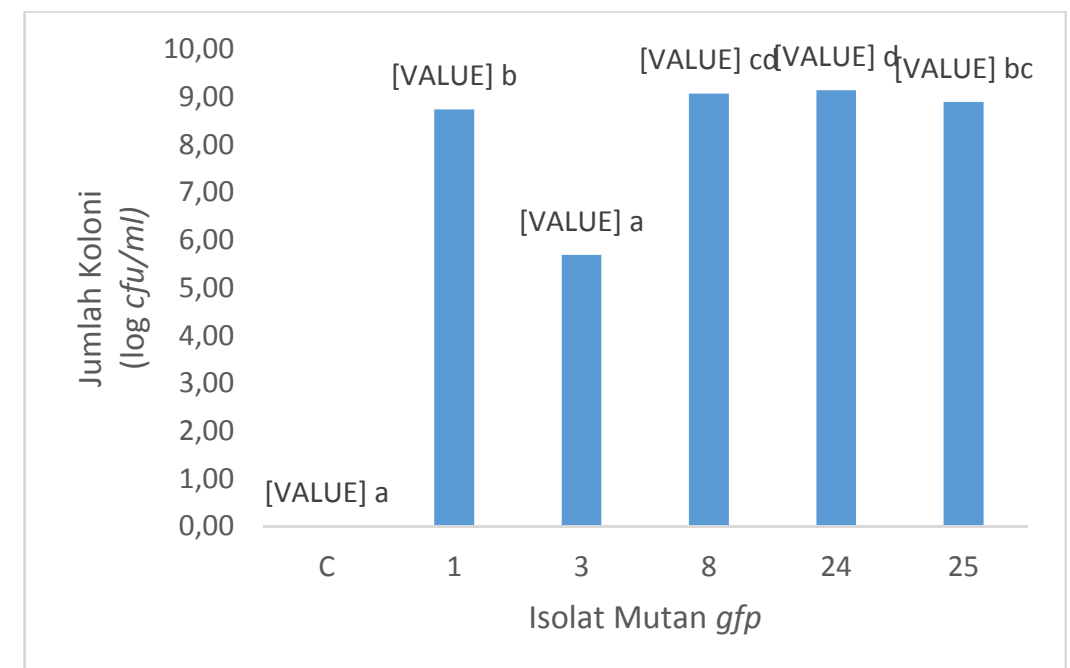

\section{Gambar 4. Jumlah Koloni pada Organ Akar Padi; C: Kontrol, 1: Mutan IM-1+gfp, 3: Mutan IM-3+gfp, 8: Mutan IM-8+gfp, 24: Mutan IM-24+gfp, 25: Mutan IM- $25+g f p$; angka-angka yang diikuti huruf yang sama menunjukkan berbeda tidak nyata pada uji BNJ 5\%}

Distribusi bakteri endofitk menyebar melalui jaringan pembuluh angkut (Xilem \& Floem) dan akan memberikan pola interaksi yang berbeda dari masing masing organ tanaman. Distribusi bakteri yang cenderung berada pada organ akar menunjukkan bahwa terdapat keunikan tersendiri pada organ tersebut. Keunikan inilah yang menyebabkan bakteri dominan/ cenderung lebih tinggi berada di akar. Beberapa keunikan pada akar dikaitkan dengan adanya exudate / senyawa yang dikeluarkan oleh akar untuk metabolisme bakteri. Jiménez et. al. (2003) menyebutkan bahwa asam amino dan karbohidrat yang dihasilkan oleh akar dalam excudate akar akan berbeda pada umur tanaman. Eksudat inilah yang digunakan oleh mikroorganisme termasuk bakteri endofitik dalam metabolisme mikroorganisme.

\section{Organ Batang}

Berdasarkan pada Gambar 5 terlihat bahwa Mutan IM- $8+g f p$ dan Mutan IM-1+gfp memiliki rerata jumlah koloni tertinggi dan berbeda sangat nyata dengan isolat bakteri Mutan IM-24+gfp. Berdasarkan pada penelitian Mujibur (2013) asal Isolat mutan IM- $8+g f p$ adalah pada biji beras merah sedangkan mutan IM-1+gfp berasal dari akar beras Merah. 


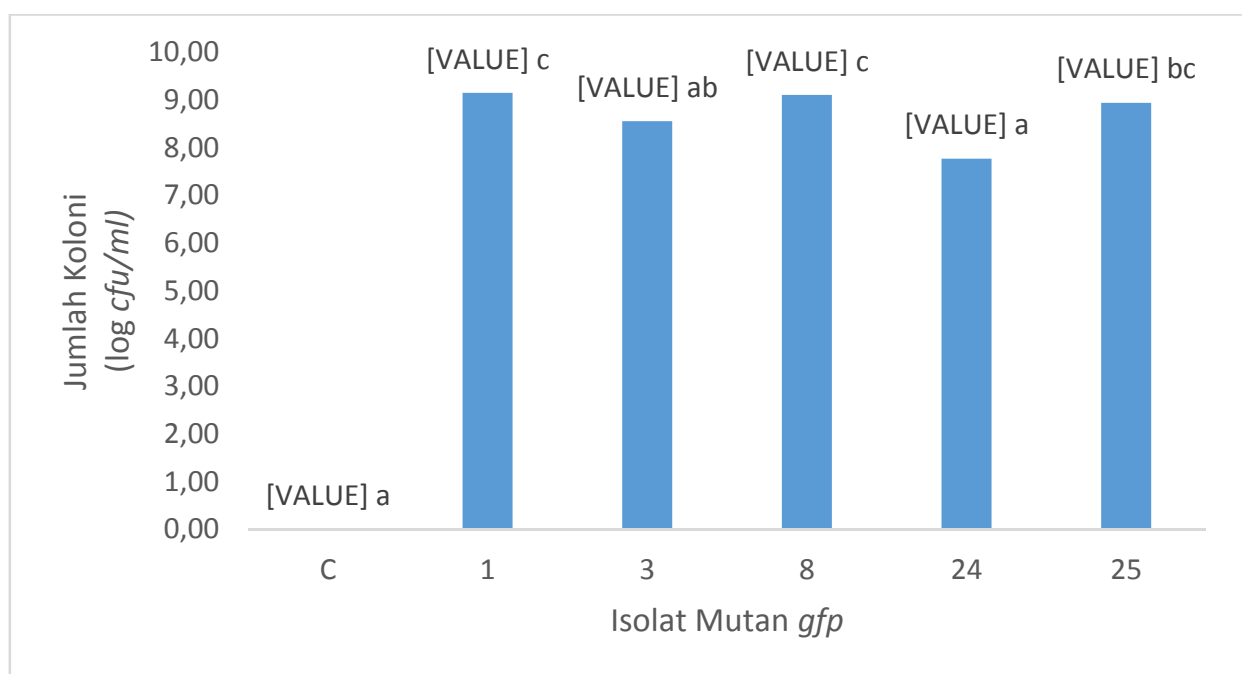

\section{Gambar 5. Jumlah Koloni pada Organ Batang Padi; C: Kontrol, 1: Mutan IM-1+gfp, 3: Mutan IM-3+gfp, 8: Mutan IM-8+gfp, 24: Mutan IM-24+gfp, 25: Mutan IM- $25+g f p$; angka-angka yang diikuti huruf yang sama menunjukkan berbeda tidak nyata pada uji BNJ 5\%}

Asal isolat dapat dijadikan referensi pembahasan karena melalui asal isolat inilah kemampuan dan pola interaksi bakteri dapat diketahui. Akan tetapi isolat mutan IM- $8+g f p$ dan mutan IM-1+gfp bukan berasal dari batang padi melainkan akar dan biji. Jika ditinjau dari asal isolatnya, seharusnya distribusi bakteri sesuai dengan asal isolat yang ada. hal ini dikarenakan isolat yang digunakan mengalami perubahan distribusi dan pola interaksi yang dikarenakan isolat merupakan hasil transformasi gen $g f p$ yang mana pada proses transformasi gen akan menjadikan gen penerima untuk menyesuaikan dengan gen baru dan kemungkinan adanya mutasi gen dan perubahan gen sangatlah besar. Perubahan yang dimaksudkan akan mempengaruhi dalam segi sintesis metabolit sekunder dan pola langsung yang diterima oleh tanaman.

\section{Organ Daun}

Pada Gambar 6 menunjukkan bahwa jumlah koloni pada mutan IM-25+gfp berbeda sangat nyata dengan mutan yang lain. Isolat mutan IM-25+gfp berasal dari akar padi ketan Merah, sehingga pada gambar 4 juga menunjukkan bahwa jumlah koloni pada organ akar juga relative tinggi. Seperti yang disebutkan bahwa terjadi perubahan dalam distribusi bakteri dikarenakan isolat yang digunakan adalah isolat mutan yang telah tersisipi gen $g f p$. Distribusi bakteri dapat terjadi melalui jaringan pembuluh angkut yang melalui kelarutan dalam air. 


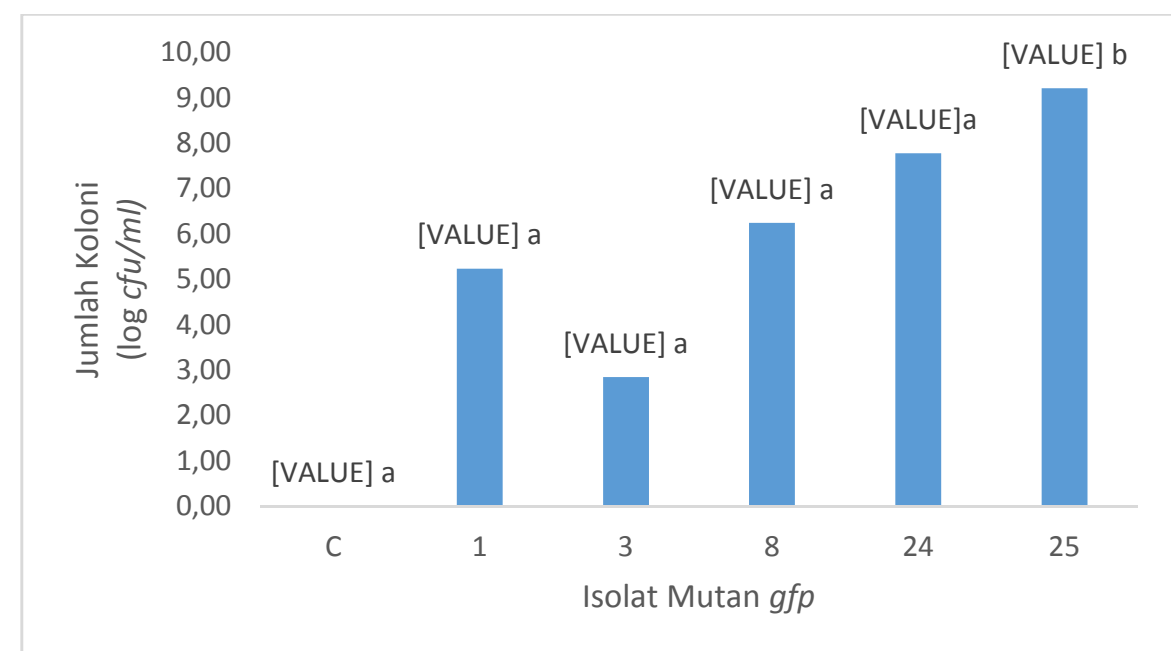

Gambar 6. Jumlah Koloni pada Organ Daun Padi; C: Kontrol, 1: Mutan IM-1+gfp, 3: Mutan IM-3+gfp, 8: Mutan IM-8+gfp, 24: Mutan IM-24+gfp, 25: Mutan IM$25+g f p$; angka-angka yang diikuti huruf yang sama menunjukkan berbeda tidak nyata pada uji BNJ 5\%

Distribusi bakteri berkenaan dengan adanya fungsi jaringan xylem dan floem pada tanaman. Jumlah koloni pada organ daun pada isolat mutan IM-25+gfp dimungkan adanya perpindahan bakteri dari organ akar melalui jaringan pembuluh angkut dalam kelarutannya bersama dengan mineral yang diserap akar dan masuk ke dalam jaringan daun untuk proses fotosintesis. Bakteri mutan isolat IM-25+gfp dimungkinkan ikut masuk pula dalam jaringan daun sehingga jumlah koloni yang dihasilkan lebih tinggi dari isolat lain.

\section{Rerata Koloni pada Masing-Masing Isolat Bakteri Mutan $g f p$}

Pada Tabel 3 menunjukkan bahwa terdapat interaksi antara isolat dengan organ tanaman padi. Interaksi dapat terlihat dari kecenderungan masing masing isolat dalam distribusinya pad organ tanaman padi yang berbeda. Pada isolat Mutan IM-25+gfp yang berada pada organ daun berbeda sangat nyata dengan Mutan IM-1+gfp pada organ daun. Tetapi pada Isolat Mutan IM-24+gfp berbeda sangat nyata antara organ, batang dan daun.

Perbedaan sangat nyata ini dikarenakan bakteri endofitif yang tergolong dalam PGPB memiliki pola yang berbeda baik langsung maupun tidak langsung seperti yang disebukan oleh Budiharjo (2011). Dengan adanya penyisipan gen $g f p$ dalam DNA bakteri, maka akan ada perubahan untaian DNA dan ekpresi gen yang disisipkan juga akan menampakkan perbedaan antara mutan dengan bakteri awal. Distribusi bakteri dalam jaringan tanaman padi sangat dipengaruhi oleh jenis bakteri endofitik yang ada dalam jaringan tersebut, serta pola spesifik dari masing masing bakteri endofitik. 
Tabel 3. Rerata Jumlah Koloni Masing-Masing Isolat pada Beberapa Organ Tanaman

\begin{tabular}{|c|c|}
\hline Isolat & Jumlah Koloni $(c f u / m l)$ \\
\hline Kontrol Akar & $0.00 \mathrm{a}$ \\
\hline Kontrol Batang & $0.00 \mathrm{a}$ \\
\hline Kontrol Daun & $0.00 \mathrm{a}$ \\
\hline Mutan IM $1+g f p$ Akar & $5.57 \times 10^{8} \mathrm{ab}$ \\
\hline Mutan IM $1+g f p$ Batang & $1.436 \times 10^{9} \mathrm{de}$ \\
\hline Mutan IM $1+g f p$ Daun & $17.33 \times 10^{4} \mathrm{a}$ \\
\hline Mutan IM $1+g f p$ Akar & $3.33 \times 10^{6} \mathrm{a}$ \\
\hline Mutan IM $3+g f p$ Batang & $3.67 \times 10^{8} \mathrm{ab}$ \\
\hline Mutan IM $3+g f p$ Daun & $7.00 \times 10^{2} \mathrm{a}$ \\
\hline Mutan IM $8+g f p$ Akar & $1.19 \times 10^{9} \mathrm{cde}$ \\
\hline Mutan IM $8+g f p$ Batang & $1.3 \times 10^{9} \mathrm{cde}$ \\
\hline Mutan IM $8+g f p$ Daun & $1.767 \times 10^{6} \mathrm{a}$ \\
\hline Mutan IM $24+g f p$ Akar & $1.42 \times 10^{9} \mathrm{de}$ \\
\hline Mutan IM $24+g f p$ Batang & $6 \times 10^{7} \mathrm{a}$ \\
\hline Mutan IM $24+g f p$ Daun & $6 \times 10^{7} \mathrm{a}$ \\
\hline Mutan IM $25+g f p$ Akar & $8.07 \times 10^{8} \mathrm{bc}$ \\
\hline Mutan IM $25+g f p$ Batang & $8.97 \times 10^{8} \mathrm{bcd}$ \\
\hline Mutan IM $25+g f p$ Daun & $1.643 \times 10^{9} \mathrm{e}$ \\
\hline BNJ 5\% & $596,353,846.82$ \\
\hline
\end{tabular}

Keterangan : angka-angka yang diikuti huruf yang sama pada kolom yang sama menunjukkan berbeda tidak nyata pada Uji BNJ taraf 5\%

\section{KESIMPULAN}

Hasil penelitian tahap I disimpulkan bahwa tahap invasi awal dalam pola interaksi bakteri pada persentase imbibisi menunjukkan 5 isolat bakteri endofitik mutan $g f p$ berkisar antara 4\%-17\%, tertinggi isolat Mutan IM-3 +gfp (17\%) terendah Isolat Mutan IM-8+gfp (4\%), tidak berbeda nyata pada parameter waktu perkecambahan benih, isolat Mutan IM$1+g f p$ dan IM-8+gfp lebih tinggi pada organ batang, Isolat Mutan IM-24+gfp lebih tinggi pada organ akar, dan Isolat Mutan IM-25+gfp lebih tinggi pada organ daun. Hasil penelitian tahap II dapat disimpulkan bahwa mutan IM-25+gfp pada daun memiliki rerata jumlah koloni tertinggi yakni $1.643 \times 10^{9} \mathrm{cfu} / \mathrm{ml}$.

\section{UCAPAN TERIMA KASIH}

Disampaikan terimaksih kepada DRPM, KEMENRISTEKDIKTI yang telah membiayai penelitian ini dengan Surat Keputusan Nomor:02//E.1/KPT/2017 dan Perjanjian/Kontrak Nomor 019/SP2H/K2/KM/2017 


\section{DAFTAR PUSTAKA}

BPS. 2016. Produksi Padi, Jagung, Dan Kedelai (Angka Sementara Tahun 2015). No. 26/03/ Th. XIX, 01 Maret 2016. www.bps.go.id diakses tanggal 20 Desember 2016

Budiharjo, Anto. (2011). Plant-Bacteria Interactions: Molecular Mechanisms of Phytostimulation by Bacillus amyloliquefaciens FZB42 [Dissertation]. University of berlin.

Campbell, N.A., Reece, J.B., dan Mitchell, L.G.a. (2003). Biologi Jilid 2. Jakarta: Penerbit Erlangga.

Maftuchah. (2012). Rekayasa Genetik Padi Indica. Yogyakarta: Buku Litera.

Jiménez, M.B., Florest, S.A., Zapata, E.V., Campos, E.P., Bouquelet, S.. Zenteno, E. (2003). Chemical characterization of root exudates from rice (oryza sativa) and their effect on the chemotactic response of endophytic bacteria. Plant and Soil. 249:271-277.

Kamil, J. (1979). Teknologi Benih 1. Padang: Angkasa Raya.

Mattos, K.A., Pádua V.L.M., Romeiro, A., Hallack, L.F., Neves, B.C., Ulisses, T.M.U., Barros, C.F., Todeschini, A.R., Previato, J.O. And Previato, L.M.. 2008. Endophytic Colonization Of Rice Oryza Sativa L) By The Diazotrophic Bacterium Bukholderia Kukuriensis And Its Ability O Enchance Plant Growth. Annals of the Brazilian Academy of sciences. 80(3):477-493.

Mujibur, M.R. (2013). Isolasi dan Uji Potensi Bakteri Endofit dari Empat Jenis Tanaman Padi dalam Menambat $N$ dan Mensintesis Hormon IAA Ekstraseluler. [Skripsi] Malang. Fakultas Pertanian-Peternakan. Universitas Muhammadiyah Malang.

Purnamaningsih, R. (2006). Induksi Kalus dan Optimasi Regenerasi Empat Varietas Padi Melalui Kultur In Vitro. J. Agrobiogen. 2 (2): 74-80.

Salisbury, F.B. and C.W. Ross. (1992). Plant Physiology, 4th Ed. Wadswoth Publishing Co.

Sutopo, L. (2002). Teknologi Benih. Malang: Fakultas Pertanian UNBRAW.

Tjitrosomo, S. S., (1985). Botani Umum 2. Bandung: Angkasa 